\title{
Surface Modification of Porous Photoelectrode Using Etching Process for Efficiency Enhancement of ZnO Dye-Sensitized Solar Cells
}

\author{
Sutthipoj Sutthana, ${ }^{1}$ Duangmanee Wongratanaphisan, ${ }^{1,2}$ Atcharawon Gardchareon,,2 \\ Surachet Phadungdhitidhada, ${ }^{1,2}$ Pipat Ruankham, ${ }^{1,2}$ and Supab Choopun ${ }^{1,2}$ \\ ${ }^{1}$ Department of Physics and Materials Science, Faculty of Science, Chiang Mai University, Chiang Mai 50200, Thailand \\ ${ }^{2}$ Thailand Center of Excellence in Physics (ThEP Center), CHE, Bangkok 10400, Thailand
}

Correspondence should be addressed to Supab Choopun; supab99@gmail.com

Received 24 May 2016; Accepted 26 June 2016

Academic Editor: Meiyong Liao

Copyright ( $) 2016$ Sutthipoj Sutthana et al. This is an open access article distributed under the Creative Commons Attribution License, which permits unrestricted use, distribution, and reproduction in any medium, provided the original work is properly cited.

\begin{abstract}
Surface modification of porous $\mathrm{ZnO}$ photoelectrode using one- and two-step etching process is investigated for enhancing power conversion efficiency of $\mathrm{ZnO}$ dye-sensitized solar cells. $\mathrm{ZnO}$ films are modified by the diluted $\mathrm{NH}_{4} \mathrm{OH}$ solutions for one-step etching process and used as photoelectrode of dye-sensitized solar cells. Rough porous films are observed after one-step etching process. The fabricated cells based on the optimized one-step etched films show a significant increase in short-circuit current density. The short-circuit current density is directly changed with amount of dye adsorption, which is related to specific surface area. The etched films exhibit higher specific surface area over two times than nonetched films. Thus, the large specific surface area is the key success for increasing amount of dye adsorption. Internal electrochemical property of fabricated cells is also improved, indicating that chemical surface of $\mathrm{ZnO}$ films is modified in the same time. The DSSCs fabricated on two-step etched films with $\mathrm{NH}_{4} \mathrm{OH}$ and mixed acid $\mathrm{HCl}: \mathrm{HNO}_{3}$ show the maximum power conversion efficiency of $2.26 \%$. Moreover, fill factor is also increased due to better redox process because of the formation of fine porous structure during the etching process. Therefore, these results implied that the roles of etching processes are improving specific surface area and fine porous formation which can provide better dye adsorption and redox process for dye-sensitized solar cell application.
\end{abstract}

\section{Introduction}

Dye-sensitized solar cell (DSSC) is one of the attractive solar cells over the past two decades due to various advantages such as relative high efficiency, easy and simple fabrication process on both rigid and flexible substrates, and nontoxicity, low cost, and environmental friendly raw materials $[1,2]$. In addition, DSSCs can open huge opportunities for commercial large-scale production such as possibilities to design solar cell with shape flexibility, lightweight, color, and transparency products [3]. Typically, DSSC consists of photoelectrode $(\mathrm{PE})$, counterelectrode (CE), and electrolyte (EL) $[4,5]$. Each component of DSSC is intensively researched in order to enhance power conversion efficiency (PCE). Photoelectrode is considered to be an effective component of DSSC in PCE enhancement due to a key role in controlling photoconversion process such as dye adsorption, light scattering, charge separation, and electron transportation [6-8]. To improve the photoconversion process, surface modification of photoelectrode has been successfully applied for PCE enhancement by using various techniques. The surface treatment of $\mathrm{ZnO}$ photoelectrode by controlling temperature has been studied [9] and it was found that PCE is higher at optimum temperature due to an increase of surface area for dye adsorption. The other technique is using double-layer structure films with different particle size to improve light scattering in the photoelectrode [7]. The larger particle size is coated on the smaller particle size to form a scattering layer 
which plays an important role in increasing light scattering and decreasing electron scattering in the photoelectrode and at the same time resulting in higher PCE. Plasma etching is also an attractive technique for surface modification. The etching process creates porous structure via reactive ion etching (RIE). The pore size, shape, and distribution can be controlled by selecting appropriate reactive gases and flow rate [10]. However, plasma etching is an expensive technique due to vacuum system requirement. Wet chemical etching is an alternative technique which gains a lot of attention due to a low cost, simple, and short-time process. The chemical reaction in chemical etching can create crater-like morphology of oxide films which increases specific surface area and provides better dye adsorption [11]. Moreover, there are a large variety of chemical etchants that can be used in the etching process such as $\mathrm{HCl}, \mathrm{HF}, \mathrm{HNO}_{3}, \mathrm{KOH}, \mathrm{NaOH}$, and $\mathrm{NH}_{4} \mathrm{Cl}$ [11-14].

In this work, surface modification of porous $\mathrm{ZnO}$ photoelectrode using one- and two-step etching process is investigated for enhancing power conversion efficiency of $\mathrm{ZnO}$ dyesensitized solar cells. Wet chemical etching process of diluted base $\left(\mathrm{NH}_{4} \mathrm{OH}\right)$ solutions in distilled water is a promising simple process to improve specific surface area of $\mathrm{ZnO}$ photoelectrode, and mixed acid solution of $\mathrm{HCl}: \mathrm{HNO}_{3}$ in distilled water is used to form fine porous structure. Increment of dye adsorption is expected due to the increased specific surface area after the surface modification. The amount of dye adsorption is directly correlated to the amount of generated electrons which can be observed in terms of short-circuit current density $\left(J_{\mathrm{sc}}\right)$. Finally, power conversion efficiency of DSSC is expected to be enhanced by the optimized condition.

\section{Experimental Details}

2.1. Preparation of Photoelectrode. $\mathrm{ZnO}$ nanoparticle films were deposited onto fluorine-doped tin oxide (FTO) glass substrates by screen printing technique. Commercial FTO glass substrates were carefully cleaned with detergents, distilled water, acetone, and ethanol in an ultrasonic bath for $10 \mathrm{~min}$ each. They were then dried in air before depositing $\mathrm{ZnO}$ nanoparticle films. $\mathrm{ZnO}$ paste for screen printing was prepared by mixing $\mathrm{ZnO}$ nanoparticle in polyethylene glycol (PEG) solution. The PEG solution was prepared by dissolving $10 \%$ PEG by weight in distilled water, mixed by magnetic stirrer at room temperature. The $\mathrm{ZnO}$ paste was then screened onto FTO glass substrates and sintered at $400^{\circ} \mathrm{C}$ for $1 \mathrm{hr}$ for calcinations and removal of any residual in the films.

2.2. Wet Chemical Etching Process of Photoelectrode. The calcined $\mathrm{ZnO}$ films were modified using a wet etching process. In the one-step etching process, a $5 \%$ concentration of $\mathrm{NH}_{4} \mathrm{OH}$ in distilled water was used to etch the $\mathrm{ZnO}$ films at different etching times of 1,2 , and $3 \mathrm{~min}$. Then, the films were immediately rinsed several times with flowing distilled water and dried in air using hot air blower. Finally, the films were annealed at $120^{\circ} \mathrm{C}$ for $30 \mathrm{~min}$. In the two-step etching process, the one-step etched films were repeatedly etched by mixed acid solution of $\mathrm{HCl}: \mathrm{HNO}_{3}$ : distilled water in volume ratio of $3: 7: 44$ for $10 \mathrm{~s}$, rinsed, dried and annealed.
2.3. Fabrication of Dye-Sensitized Solar Cell. Dye molecules were loaded into the etched films using readsorption technique similar to that reported elsewhere [15]. The $\mathrm{ZnO}$ films, as photoelectrode, were immersed in dye solution at room temperature under dark condition for $1 \mathrm{hr}$ for adsorption process. After the adsorption process, the photoelectrode was immersed in ethanol for $1 \mathrm{hr}$ for deadsorption process. Finally, the photoelectrode was repeatedly immersed in dye solution with the same condition for readsorption process. After $1 \mathrm{hr}$, it was rinsed with ethanol for several seconds. Eosin-Y (EY) and N719 are used as dye sensitizers. The dye solution was prepared by dissolving $0.6 \mathrm{mM} \mathrm{EY}$ in absolute ethanol and stirring for $1 \mathrm{hr}$ to form a homogenous solution and dissolving $0.6 \mathrm{mM}$ N719 in acetone nitride/tert-butanol $(1 / 1, \mathrm{v} / \mathrm{v})$.

Pt counterelectrode was prepared by dropping a $20 \mu \mathrm{L}$ $\mathrm{H}_{2} \mathrm{PtCl}_{6}$ solution in acetone onto FTO glass substrates and sintered at $550^{\circ} \mathrm{C}$ for $1 \mathrm{hr}$. A DSSC was fabricated by sandwiching a loaded-dye photoelectrode, a Pt counterelectrode, a polymer film, and electrolyte. The electrolyte for EY was prepared by dissolving $0.2 \mathrm{M} \mathrm{LiI}$ and $0.02 \mathrm{M} \mathrm{I}_{2}$ in propylene carbonate, and the electrolyte for N719 was prepared by dissolving 0.2 M LiI, 0.02 $\mathrm{M} \mathrm{I}_{2}$, and 0.2 M DMPII in acetone nitride.

2.4. Characterization. Morphology and cross section of $\mathrm{ZnO}$ films were observed by field emission scanning electron microscopy (FE-SEM, JEOL JSM-6335F) operating at a voltage of $15.0 \mathrm{kV}$. Specific surface area (SSA) was measured by the Brunauer-Emmett-Teller (BET, Quantachrome Autosorb $1 \mathrm{MP}$ ) method using $\mathrm{N}_{2}$ gas. Dye adsorption was measured using UV-Vis-NIR spectroscopy (Varian Cary 50, wavelength range 190-1100 nm). Raman shifts were characterized by Raman spectroscopy (T64000 HORIBA JobinYvon) using $50 \mathrm{~mW}$ and $514.5 \mathrm{~nm}$ wavelength Ar green laser. Photovoltaic characteristics were measured under standard simulated solar radiation of $100 \mathrm{~mW} / \mathrm{cm}^{2}$ (AM1.5). Electrochemical properties were characterized using electrochemical impedance spectroscopy (EIS) with frequency range of $10 \mathrm{kHz}$ to $1 \mathrm{~Hz}$ and $\mathrm{AC}$ amplitude of $20 \mathrm{mV}$.

\section{Results and Discussion}

3.1. Morphological Characteristics of Etched ZnO Films. Surface morphology of one-step etched $\mathrm{ZnO}$ films was shown in Figure 1. The porous structures were observed from the top view FE-SEM images after etching process. The rough porous formation on the $\mathrm{ZnO}$ films was observed due to chemical reactions that can be represented by the following equations $[16,17]$ :

$$
\begin{aligned}
\mathrm{NH}_{4} \mathrm{OH} & \longrightarrow \mathrm{NH}_{4}^{+}+\mathrm{OH}^{-} \\
\mathrm{NH}_{4}{ }^{+}+\mathrm{H}_{2} \mathrm{O} & \longrightarrow \mathrm{NH}_{3}+\mathrm{H}_{3} \mathrm{O}^{+} \\
\mathrm{ZnO}+2 \mathrm{H}_{3} \mathrm{O}^{+} & \longrightarrow \mathrm{Zn}^{2+}+3 \mathrm{H}_{2} \mathrm{O} \\
\mathrm{Zn}^{2+}+2 \mathrm{OH}^{-} & \longrightarrow \mathrm{Zn}(\mathrm{OH})_{2}
\end{aligned}
$$




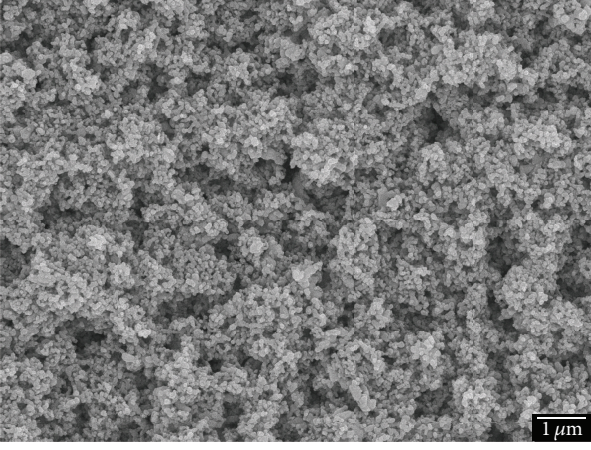

(a)

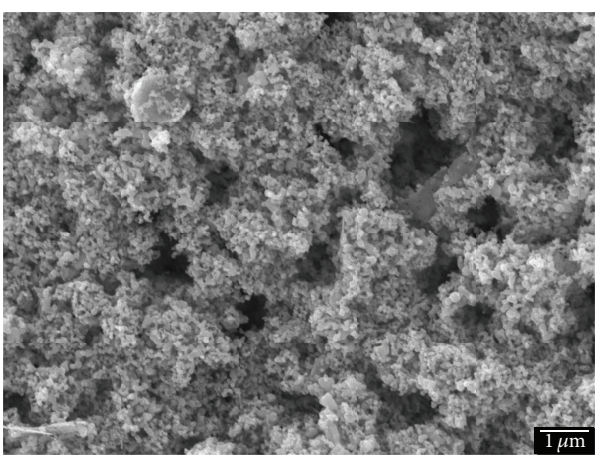

(c)

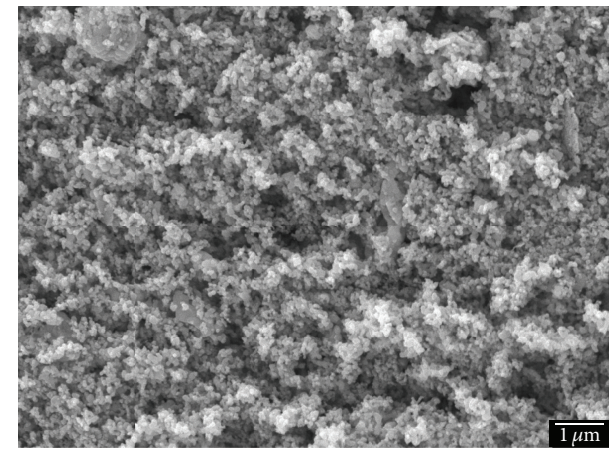

(b)

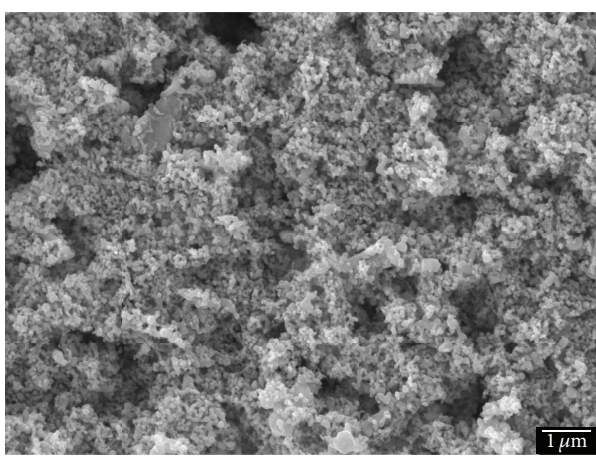

(d)

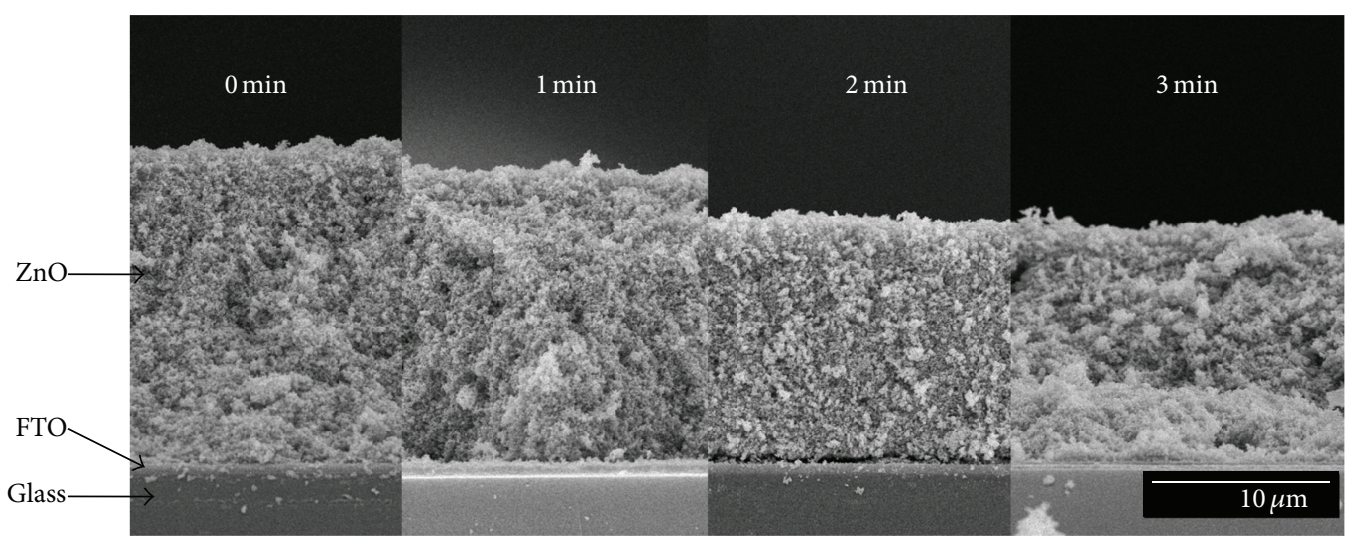

(e)

Figure 1: Morphology of $\mathrm{ZnO}$ films etched by $\mathrm{NH}_{4} \mathrm{OH}$ solutions with various etching time; (a) $0 \mathrm{~min}$, (b) $1 \mathrm{~min}$, (c) $2 \mathrm{~min}$, (d) $3 \mathrm{~min}$, and (e) cross-sectional image.

Hydronium ion $\left(\mathrm{H}_{3} \mathrm{O}^{+}\right)$reacts on electron at oxygen site of $\mathrm{ZnO}$. The $\mathrm{OH}^{-}$will continuously react with $\mathrm{Zn}^{2+}$ at the surface to form $\mathrm{Zn}(\mathrm{OH})_{2}$ and remove $\mathrm{ZnO}$ particles from the surface. The reaction creates the pore position at the reaction site forming a rough porous structure. Since the base solutions have slow reaction, $1 \mathrm{~min}$ etching time is not enough to remove the dense particles as seen in Figure 1(b). On the other hand, 3 min etching time is too long and porous structure is destructed (Figure 1(d)). However, the etching time of 2 min showed optimum time with high-ordered porous films (Figure 1(c)).

The one-step etched $\mathrm{ZnO}$ films thickness was estimated from the cross-sectional FE-SEM image (Figure 1(e)) using
image-J software. The nonetched films showed the maximum thickness of $18.02 \pm 0.28 \mu \mathrm{m}$. After surface modification for 1,2 , and $3 \mathrm{~min}$, the thickness was decreased as $16.20 \pm$ $0.31,14.01 \pm 0.60$, and $13.79 \pm 0.44 \mu \mathrm{m}$, respectively. The thickness is slightly decreased with increasing etching time due to $\mathrm{ZnO}$ removal during chemical process. The etching rate of $\mathrm{ZnO}$ films by diluted $\mathrm{NH}_{4} \mathrm{OH}$ solution was estimated to be $1.49 \mu \mathrm{m} / \mathrm{min}$ by assuming the linear relation between thickness decreasing and etching time increasing.

3.2. The Brunauer-Emmett-Teller (BET) Analysis. The specific surface area of one-step etched films was measured using BET analysis to understand effects of specific surface area 


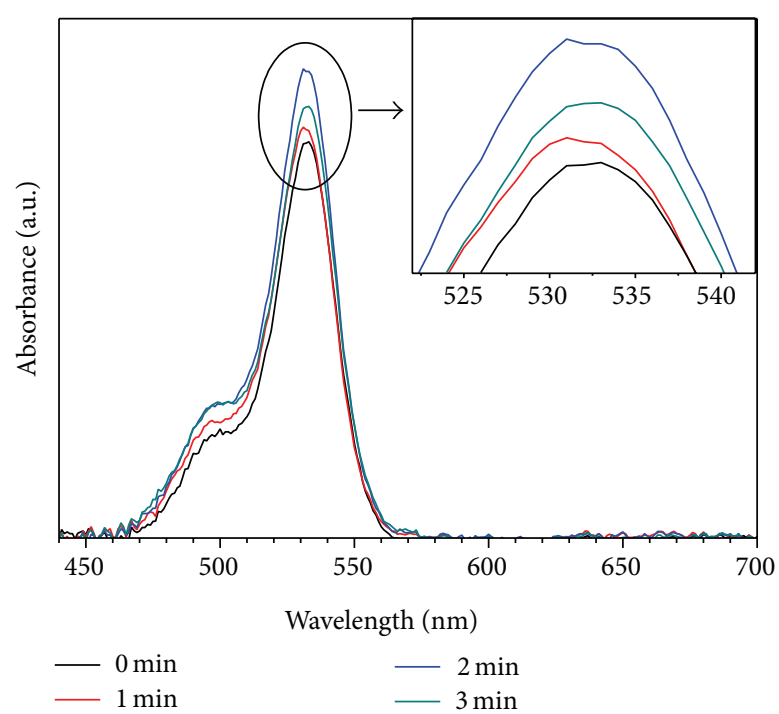

(a)

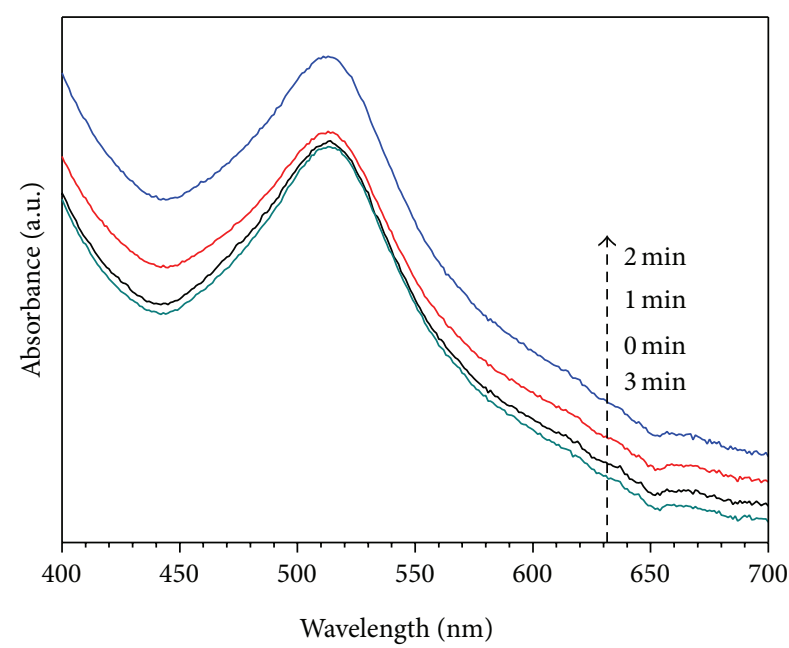

(b)

FIgURE 2: Dye adsorption with various etching time of (a) EY sensitizer and (b) N719 sensitizer.

TABLE 1: Specific surface area and dye adsorption of etched $\mathrm{ZnO}$ films.

\begin{tabular}{lccr}
\hline $\begin{array}{l}\text { Etching } \\
\text { time (min) }\end{array}$ & Specific surface area $\left(\mathrm{m}^{2} / \mathrm{g}\right)$ & \multicolumn{2}{c}{$\begin{array}{c}\text { Dye adsorption } \\
\left(10^{-9} \mathrm{~mol} / \mathrm{cm}^{2}\right)\end{array}$} \\
\hline 0 & 2.52 & EY & N719 \\
1 & 5.71 & 9.33 & 43.67 \\
2 & 5.30 & 9.65 & 44.85 \\
3 & 4.29 & 11.04 & 53.03 \\
\hline
\end{tabular}

on DSSC performance. The measured specific surface areas were listed in Table 1. It was found that the specific surface area of the etched films is rapidly increased over two times compared with the nonetched films. The specific surface area reached maximum value of $5.71 \mathrm{~m}^{2} / \mathrm{g}$ for 1 min etching time and slightly decreased for longer etching time. The result suggested that a simple modification of $\mathrm{ZnO}$ films can be effectively improved by wet chemical etching process.

3.3. Dye Adsorption Analysis. Dye concentration was investigated by extract the adsorbed dye molecules and measured absorbance spectra via UV-Vis-NIR spectroscopy as shown in Figure 2. The absorbance peaks showed the maximum value at 2 min etching time for both EY and N719. The amount of dye adsorption was evaluated by the Beer-Lambert law at the major peak wavelength as listed in Table 1 :

$$
A=c \varepsilon L
$$

where $A$ is absorbance, $c$ is dye concentration, $\varepsilon$ is molar extinction coefficient $\left(\varepsilon=89,560 \mathrm{M}^{-1} \mathrm{~cm}^{-1}\right.$ at wavelength of $532 \mathrm{~nm}$ for EY [18-20] and $\varepsilon=14,100 \mathrm{M}^{-1} \mathrm{~cm}^{-1}$ at wavelength of $515 \mathrm{~nm}$ for N719 [21, 22]), and $L$ is length of dye solution $(1 \mathrm{~cm})$. It can be seen that dye adsorption is increased at increasing etching time and optimized at the etching time of $2 \mathrm{~min}$ which corresponded to high-order porous film. Therefore, dye adsorption plays a key role in etching process of $\mathrm{ZnO}$ photoelectrode to enhance PCE of $\mathrm{ZnO}$ DSSC because change in light harvesting efficiency at a particular wavelength, $\phi_{A}\left(\lambda_{\text {ex }}\right)$, is directly considered with amount of dye adsorption according to the relation [23]

$$
\phi_{A}\left(\lambda_{\mathrm{ex}}\right)=\left(1-10^{A}\right)
$$

where $A$ is absorbance of dye adsorption at a particular wavelength. $\phi_{A}\left(\lambda_{\mathrm{ex}}\right)$ in etched films might be improved due to increased amount of dye adsorption which exhibited the most significant change for 2 min etching time.

3.4. Photovoltaic Characteristics. Current density-voltage $(J-V)$ characteristics were measured under standard test condition (AM1.5) as shown in Figure 3. In addition, calculated photovoltaic parameters including short-current density $\left(J_{\mathrm{sc}}\right)$, open-circuit voltage $\left(V_{\mathrm{oc}}\right)$, fill factor $(\mathrm{FF})$, and power conversion efficiency (PCE) are summarized in Table 2. $J_{\mathrm{sc}}$ increased, reaching maximum values of $4.77 \mathrm{~mA} / \mathrm{cm}^{2}$ and $7.15 \mathrm{~mA} / \mathrm{cm}^{2}$ for EY and N719, respectively, at 2 min etching time whereas $V_{\text {oc }}$ has small change. The result showed that PCE is improved with a direct correlation of $J_{\mathrm{sc}}$ where the films were etched by $\mathrm{NH}_{4} \mathrm{OH}$ solutions for both EY and N719. $J_{\mathrm{sc}}$ is considered as a major factor for PCE enhancement which is related to the amount of dye adsorption as shown in Figure 4. It is clearly observed that $J_{\text {sc }}$ increased with the increasing amount of dye adsorption. It was attributed that $J_{\mathrm{sc}}$ is governed by the amount of dye adsorption [24] which can be seen in terms of light harvesting efficiency, $\Phi_{\mathrm{LH}}$, according the relation [23]

$$
J_{\mathrm{sc}} \propto \Phi_{\mathrm{LH}} \Phi_{G} \Phi_{C}
$$




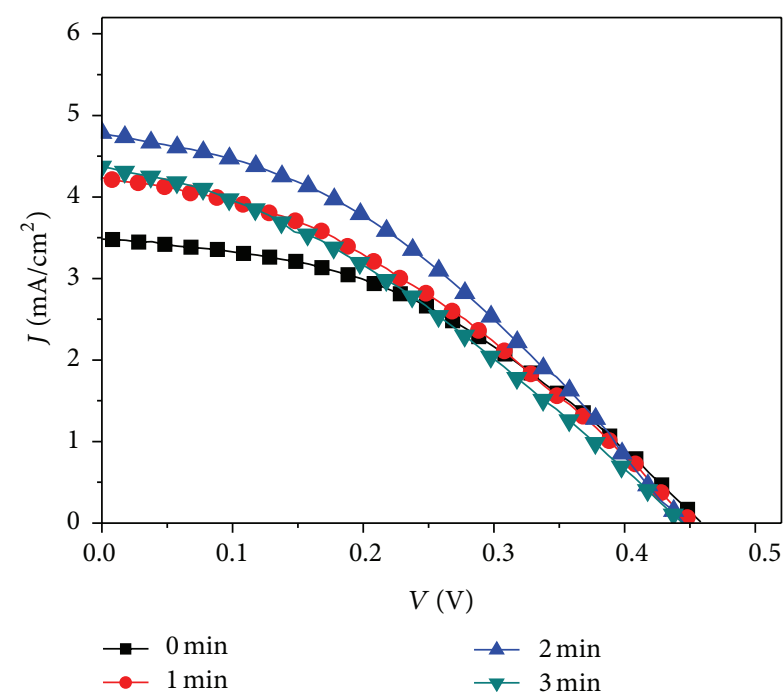

(a)

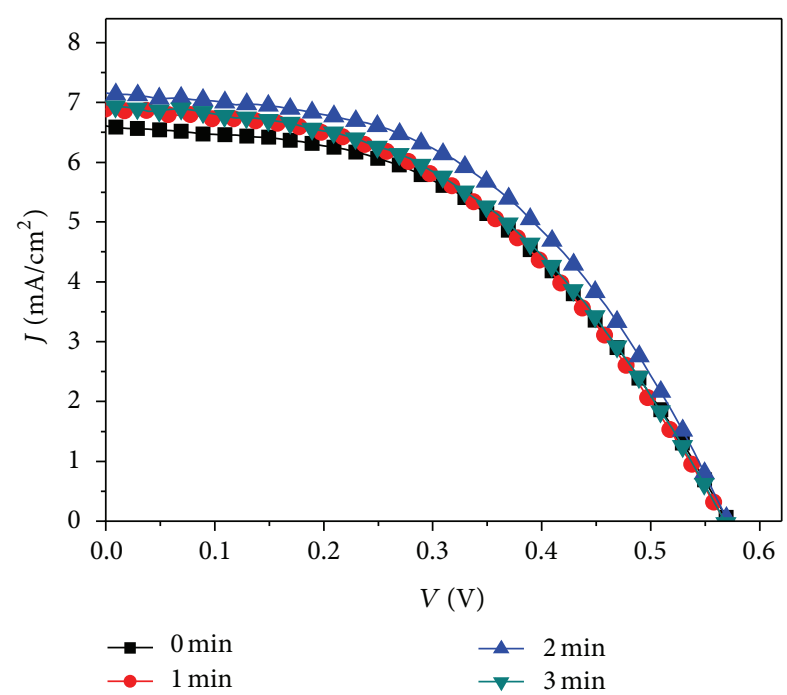

(b)

FIGURE 3: Photovoltaic characteristics of ZnO DSSC fabricated on etched films with various etching time for (a) EY sensitizer and (b) N719 sensitizer.

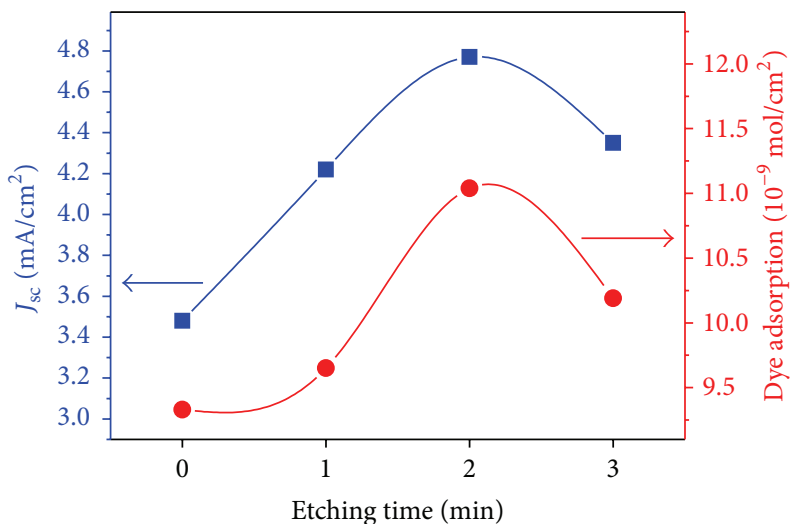

(a)

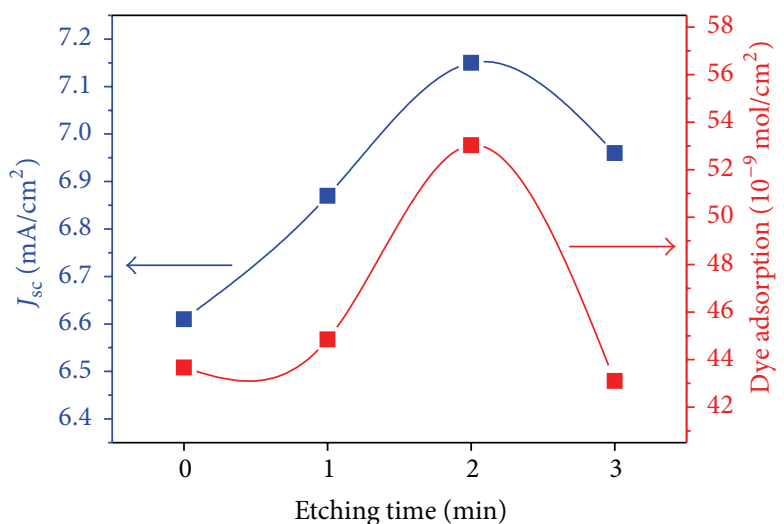

(b)

FIGURE 4: Relation of $J_{\text {sc }}$ and dye adsorption with various etching time for (a) EY sensitizer and (b) N719 sensitizer.

TABLE 2: Photovoltaic parameters and dye adsorption of ZnO DSSC fabricated on etched films.

\begin{tabular}{|c|c|c|c|c|c|}
\hline Sensitizer & Etching time (min) & $J_{\mathrm{sc}}\left(\mathrm{mA} / \mathrm{cm}^{2}\right)$ & $V_{\text {oc }}(\mathrm{V})$ & FF & PCE (\%) \\
\hline \multirow{4}{*}{ EY } & 0 & $3.48 \pm 0.08$ & $0.45 \pm 0.01$ & $0.42 \pm 0.01$ & $0.67 \pm 0.02$ \\
\hline & 1 & $4.22 \pm 0.06$ & $0.45 \pm 0.01$ & $0.37 \pm 0.03$ & $0.70 \pm 0.05$ \\
\hline & 2 & $4.77 \pm 0.47$ & $0.44 \pm 0.01$ & $0.39 \pm 0.04$ & $0.80 \pm 0.02$ \\
\hline & 3 & $4.35 \pm 0.30$ & $0.44 \pm 0.01$ & $0.35 \pm 0.01$ & $0.66 \pm 0.05$ \\
\hline \multirow{4}{*}{ N719 } & 0 & $6.61 \pm 0.26$ & $0.57 \pm 0.01$ & $0.48 \pm 0.02$ & $1.80 \pm 0.01$ \\
\hline & 1 & $6.87 \pm 0.25$ & $0.56 \pm 0.01$ & $0.47 \pm 0.01$ & $1.81 \pm 0.01$ \\
\hline & 2 & $7.15 \pm 0.32$ & $0.57 \pm 0.01$ & $0.49 \pm 0.02$ & $2.00 \pm 0.01$ \\
\hline & 3 & $6.96 \pm 0.13$ & $0.57 \pm 0.01$ & $0.47 \pm 0.01$ & $1.85 \pm 0.08$ \\
\hline
\end{tabular}

where $\Phi_{G}$ is electron generation efficiency of dye molecule under excitation condition and $\Phi_{C}$ is charge collection efficiency of $\mathrm{ZnO}$.

3.5. Electrochemical Impedance Spectroscopy (EIS) Analysis. Internal electrochemical reaction of electron in fabricated
DSSC was investigated by electrochemical impedance spectra measurement in the dark with forward bias voltage of $-0.7 \mathrm{~V}$ for steady state as shown as Nyquist plot in Figure 5. The EIS parameters were fitted using Z-view software under equivalent circuits according to the inset of Figure 5(a) [6, 25]. Three main internal resistances of $R_{s}, R_{\mathrm{ct} 1}$, and $R_{\mathrm{ct} 2}$ 


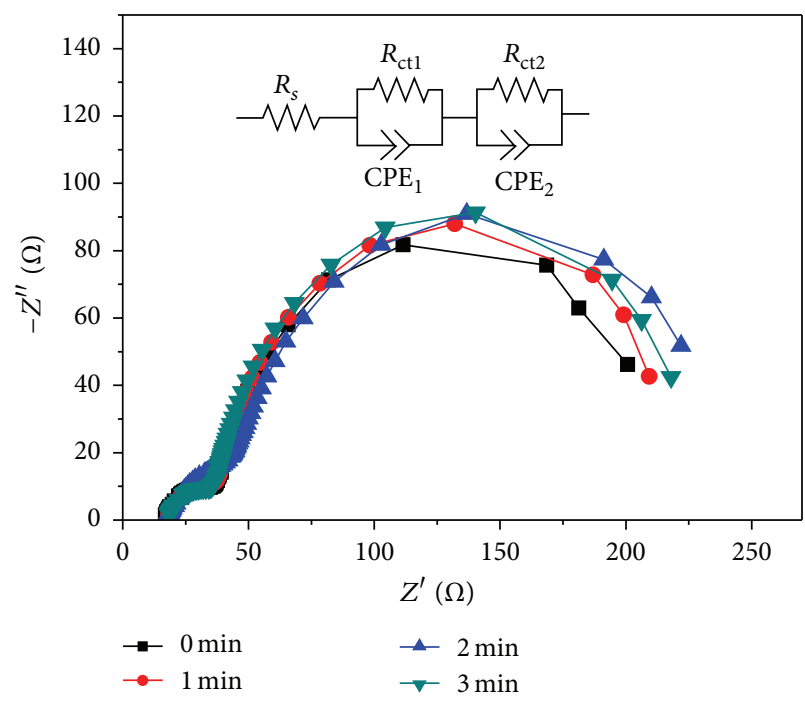

(a)

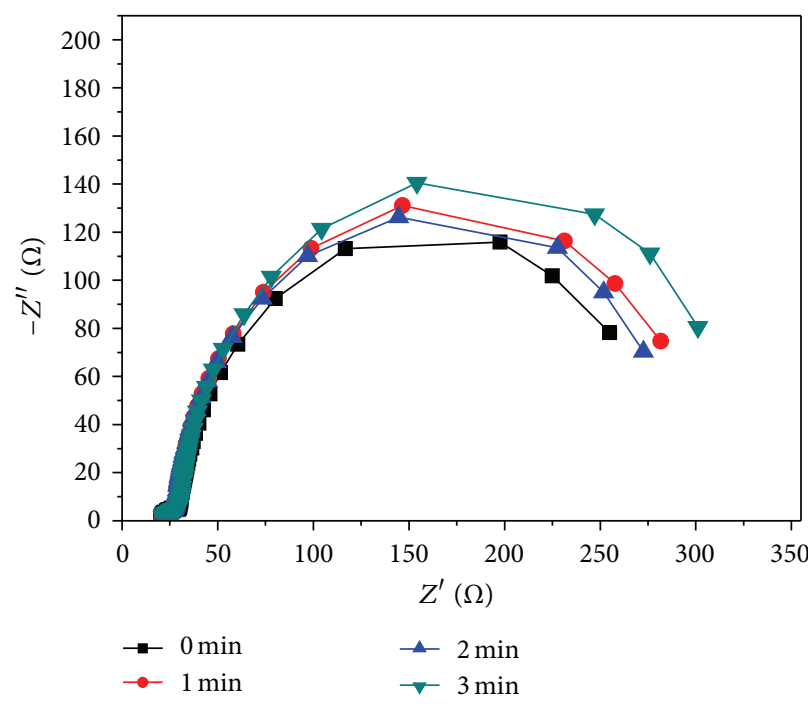

(b)

FIGURE 5: Nyquist plots of ZnO DSSC fabricated on etched films with various etching time for (a) EY sensitizer and (b) N719 sensitizer.

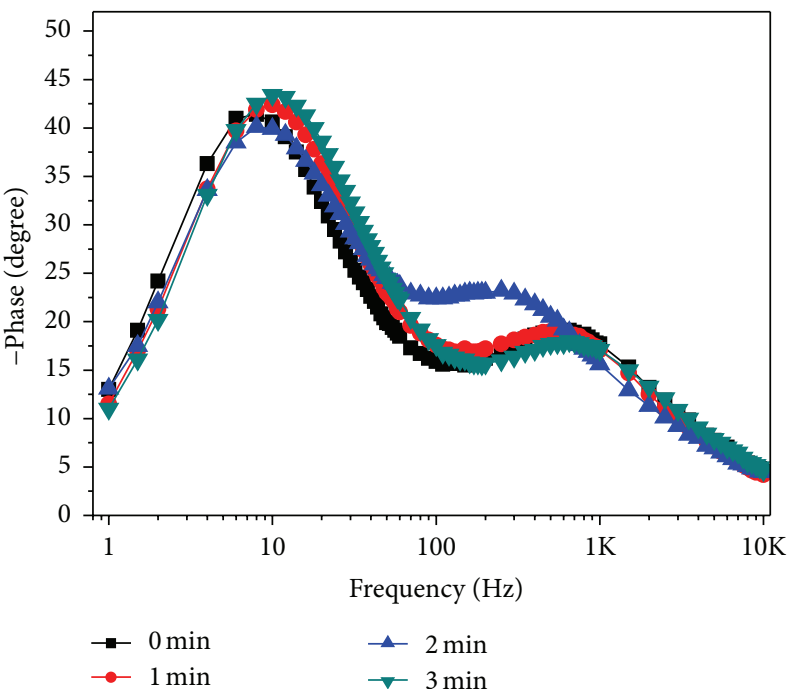

(a)

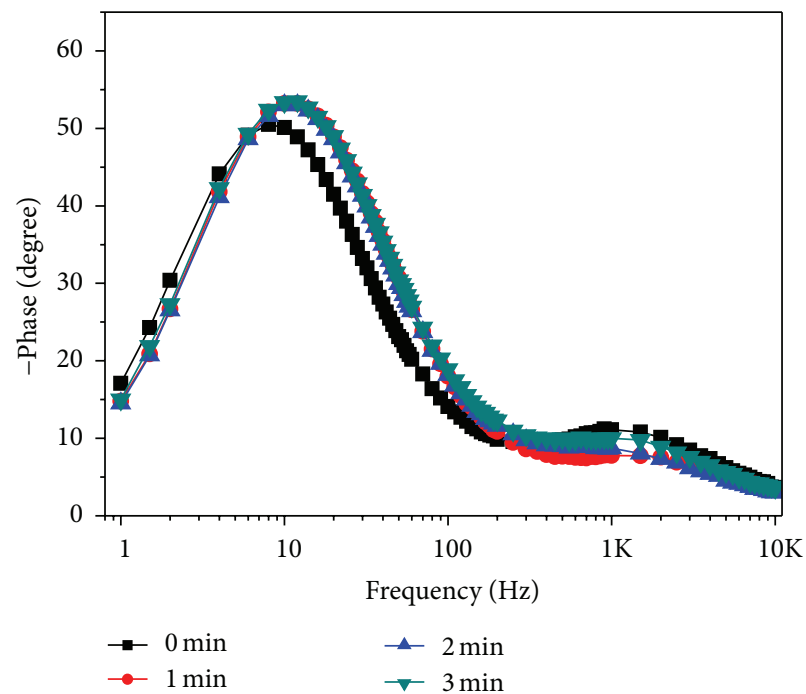

(b)

FIGURE 6: Bode phase plots of ZnO DSSC fabricated on etched films with various etching time for (a) EY sensitizer and (b) N719 sensitizer.

correspond to series resistance and charge transfer resistance at electrolyte/Pt interfaces and at $\mathrm{ZnO} /$ dye/electrolyte interfaces, respectively [26]. Constant phase element (CPE) is used for smooth fitting. Electron lifetime $(\tau)$, which means duration of electron movement in conduction band of $\mathrm{ZnO}$ before recombination with oxidized dye or electrolyte [27], was calculated from the following equation [28]:

$$
\tau=\frac{1}{2 \pi f_{\text {peak }}}
$$

where $f_{\text {peak }}$ is the frequency at the maximum peak from the Bode phase plots [28] as shown in Figure 6. The parameters were summarized in Table 3 . All of the fabricated cells based on etched $\mathrm{ZnO}$ films exhibit larger $R_{\mathrm{ct} 2}$ compared with the nonetched films. This result indicated lower recombination phenomenon at the $\mathrm{ZnO} /$ dye/electrolyte interfaces due to lower number of electrons $(n)$ involved in the reaction at the interfaces according to the following equation [29]:

$$
R_{\mathrm{ct}}=\frac{R T}{n F J_{0}}
$$

where $R$ is the gas constant, $T$ is the absolute temperature, $F$ is Faraday's constant, and $J_{0}$ is exchange current density. The recombination is reduced resulting in reduction of $J_{0}$ and increase of $J_{\mathrm{sc}}$.

Small change in $R_{s}$ can be described by change in surface resistance of FTO due to chemical reaction during the etching process. $R_{\mathrm{ct} 1}$ changed due to counterelectrode 


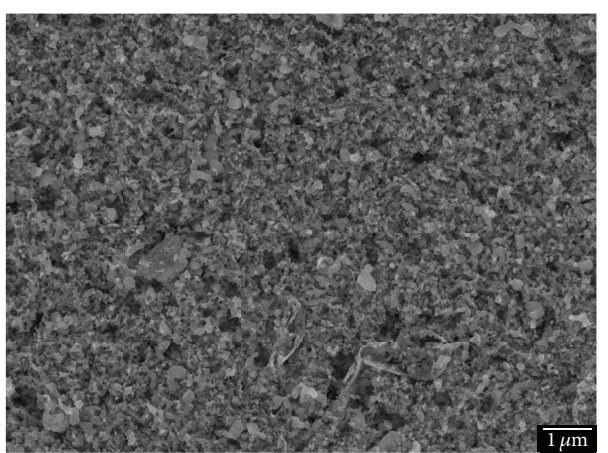

(a)

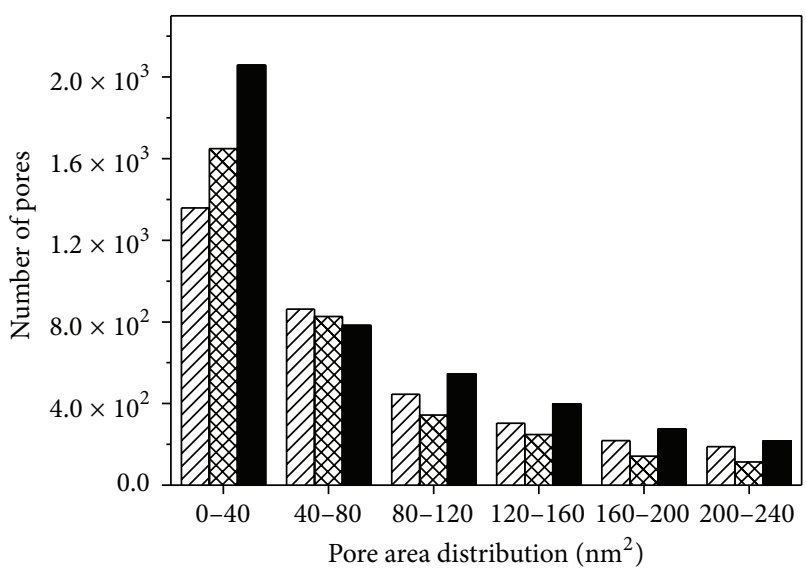

VII Nonetched films

One-step etched films Two-step etched films

(b)

FIGURE 7: Morphology of two-step etched $\mathrm{ZnO}$ films (a) and comparative pore area distribution (b).

TABLE 3: Electrochemical impedance parameters of ZnO DSSC fabricated on etched films.

\begin{tabular}{lcccccc}
\hline Sensitizer & $\begin{array}{c}\text { Etching } \\
\text { time }(\min )\end{array}$ & $R_{s}(\Omega)$ & $R_{\mathrm{ct} 1}(\Omega)$ & $R_{\mathrm{ct} 2}(\Omega)$ & $f_{\text {peak }}(\mathrm{Hz})$ & $\tau(\mathrm{ms})$ \\
\hline \multirow{4}{*}{$\mathrm{EY}$} & 0 & 16.8 & 22.3 & 169.6 & 8 & 19.9 \\
& 1 & 18.1 & 21.8 & 178.7 & 10 & 15.9 \\
& 2 & 17.8 & 32.2 & 179.9 & 8 & 19.9 \\
& 3 & 18.3 & 20.1 & 185.9 & 10 & 15.9 \\
\hline \multirow{4}{*}{$\mathrm{N} 719$} & 0 & 20.1 & 10.7 & 243.6 & 8 & 19.9 \\
& 1 & 21.7 & 7.3 & 267.5 & 10 & 15.9 \\
& 2 & 20.5 & 8.0 & 256.3 & 12 & 13.3 \\
& 3 & 21.2 & 9.5 & 287.7 & 12 & 13.3 \\
\hline
\end{tabular}

surface. Calculated electron lifetime showed no trends. In addition, small change in electron life time indicated that duration of electron movement in conduction band of etched $\mathrm{ZnO}$ is not much changed while the $R_{\mathrm{ct} 2}$ increased. The results suggest an improvement of electron transport in the fabricated cell. However, these internal phenomena do not significantly affect PCE when compared with the effects of dye adsorption.

3.6. Two-Step Etching Process Performance. The optimized one-step etched films with $\mathrm{NH}_{4} \mathrm{OH}$ etching process for $2 \mathrm{~min}$ were repeatedly etched by mixed acid solution for short time of $10 \mathrm{~s}$. It is well known that $\mathrm{ZnO}$ rapidly reacts with acid ions, and the small aggregate $\mathrm{ZnO}$ particles are removed to form a fine porous structure as shown in Figure 7(a). To evaluate porous structure in two-step etched film, onestep etched films, and nonetched films, image-J software is used for analyzing the pore area distribution from ordinary FE-SEM image. The FE-SEM image was converted as gray scale with 8 bits (image $\gg$ type $\gg 8$ bits) and analyzed for pore area (image $\gg$ adjust $\gg$ threshold $\gg$ auto). All samples exhibited similar trends for pore size distribution. The dominated pore size was observed in ranks of $0-40 \mathrm{~nm}^{2}$ and the count frequency of small pore size exhibited higher number of pores ( $>3$ times) than other ranks. Moreover, the two-step etched films exhibited the highest count frequency for the small pore size. This result can be described by the notion that large pore size might be etched during etching process. After the large pore size was etched, the small pore size was formed and relatively increased as seen in Figure 7 (b). The increase of small pore size $\left(0-40 \mathrm{~nm}^{2}\right)$ can ensure that fine porous structure (mesoporous structure) is formed for two-step etched films. The fine porous structure provides high specific surface area which was confirmed by the BET result. Moreover, the result agrees with the increase in number of small pore sizes. The specific surface area of two-step etched films exhibits a significant increment of value as $7.07 \mathrm{~m}^{2} / \mathrm{g}$ compared with one-step etched films $\left(5.30 \mathrm{~m}^{2} / \mathrm{g}\right)$ and nonetched films $\left(2.52 \mathrm{~m}^{2} / \mathrm{g}\right)$.

In addition, the simulated $3 \mathrm{D}$ profiles as shown in Figure 8 exhibited that the one-step etched films become rough films because the peak and trough are very different in ranks. While the two-step etched films exhibited better smooth surface, it is confirmed that rough pores are modified, and fine pores are formed after the two-step etching process. Therefore, image-J analyzing technique which is a simple image processing technique can be used to preliminarily evaluate surface area. The Raman shift was shown in Figure 9; the intensity decreased after etching process due to thickness decrease. However, Raman shift was clearly not changed after the fine porous structure formation by chemical etching process. These results indicated that fine porous structure is formed by chemical corrosion and removed small aggregate particle from $\mathrm{ZnO}$ films without leaving any species such as $\mathrm{O}$ vacancies. Therefore, high specific surface area was improved due to fine porous structure formation, which was modified by two-step etching process. 


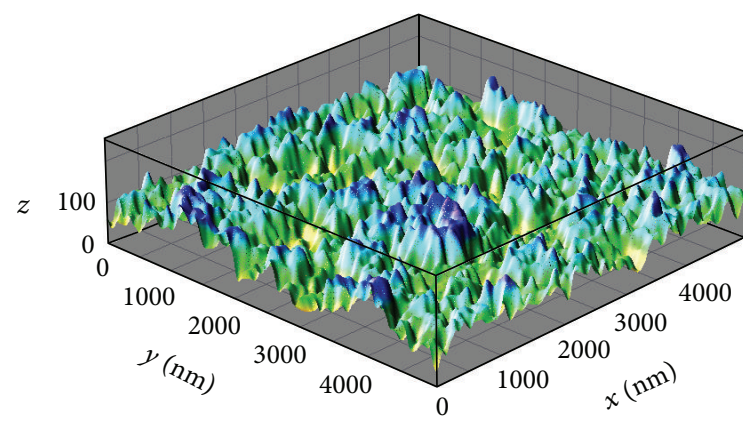

(a)
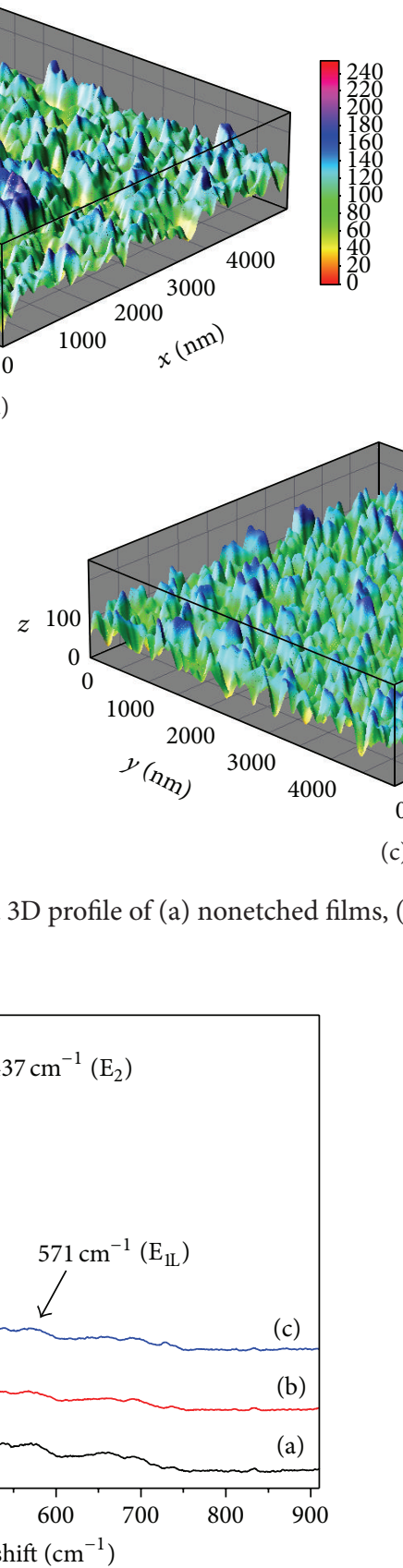

FIGURE 9: Raman shift of (a) nonetched films, (b) one-step etched

FIGURE 9: Raman shift of (a) nonetche
films, and (c) two-step etched films.

Due to the fine porous structure formation, the PCE of DSSC fabricated on two-step etched films is enhanced as $2.26 \pm 0.01 \%$ for N719 sensitizer, which is higher than both the one-step etched films and the nonetched films as shown in Figure 10. In addition, photovoltaic parameters including $J_{\mathrm{sc}}$, $V_{\mathrm{oc}}$, and $\mathrm{FF}$ are $7.49 \pm 0.05 \mathrm{~mA} / \mathrm{cm}^{2}, 0.58 \pm 0.01 \mathrm{~V}$, and $0.52 \pm$ 0.01 , respectively. An improvement of FF indicated that fine porous structure offered better interfacial contact between $\mathrm{ZnO} /$ Dye/electrolyte providing better redox process in the DSSC. This result indicated that mixed acid solution can be used to modify $\mathrm{ZnO}$ films to improve FF and enhance PCE in

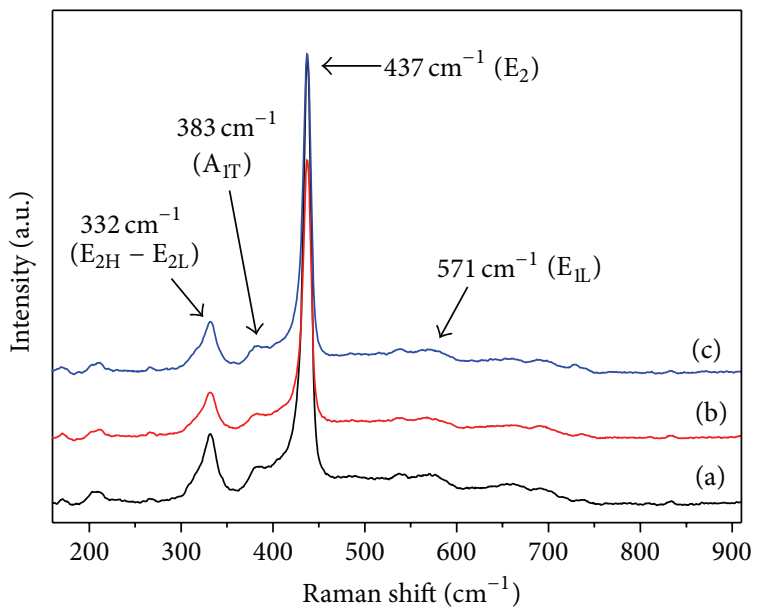

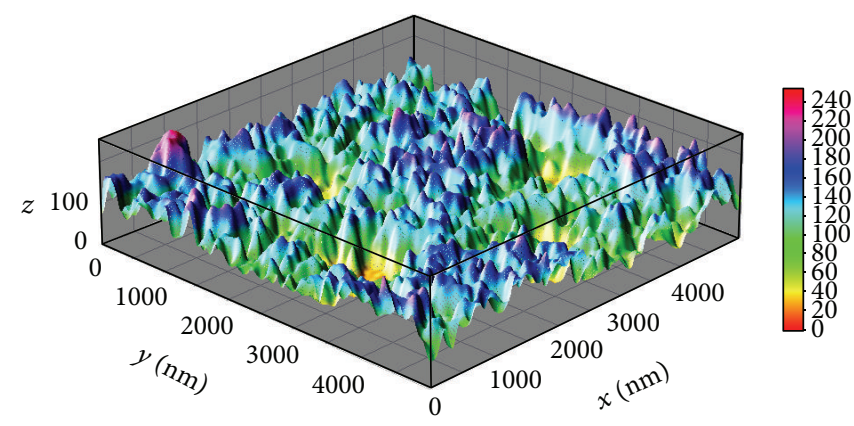

(b)

FIGURE 8: Simulated 3D profile of (a) nonetched films, (b) one-step etched films, and (c) two-step etched films.

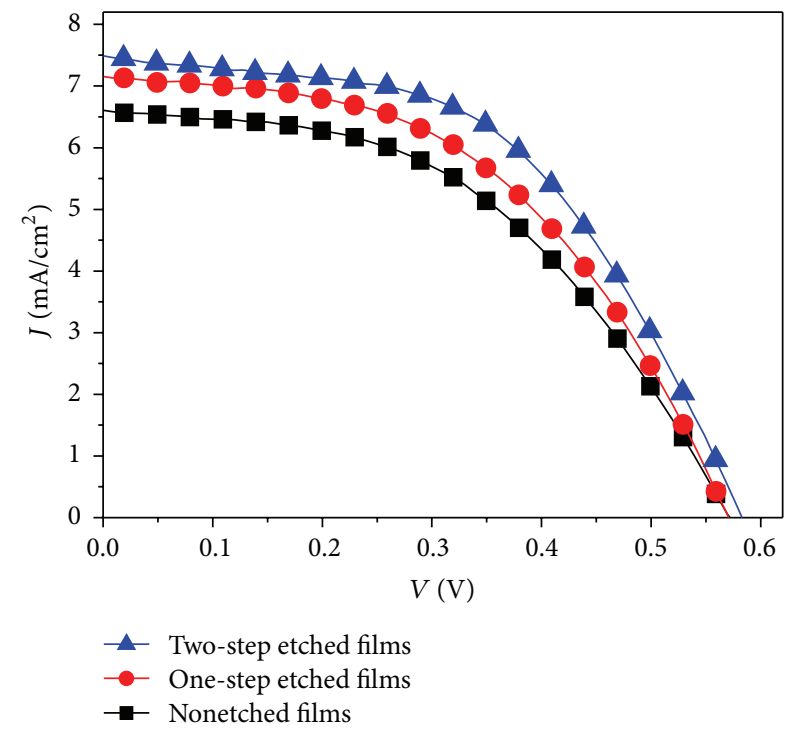

FIGURE 10: Comparative $J-V$ characteristics of DSSC fabricated on nonetched, one-step, and two-step etched $\mathrm{ZnO}$ films.

DSSC. It can be seen that the enhanced cell in this work shows a quite low PCE compared with reports and commercial cells which are in wide ranges of $0.2-11.3 \%$ [30-32]. High PCE in several reports is maybe due to the use of a different semiconductor material such as $\mathrm{TiO}_{2}$ with nanostructures such as nanorods, a complicating treatment in many parts of DSSCs, and production technology for device development. However, a simple method for photoelectrode modification 
using etching process in this report is applied effectively and confirmed an ability to enhance cell performance.

\section{Conclusions}

Power conversion efficiency of $\mathrm{ZnO}$ dye-sensitized solar cell fabricated on modified photoelectrode is enhanced due to high specific surface area, which is supported by the fine porous structure. The optimized etched $\mathrm{ZnO}$ photoelectrode by the wet chemical etching process can also improve higher dye adsorption due to an increase in specific surface area. Increased amount of dye adsorption resulted in high shortcircuit current density. Thus, high specific surface area is the major factor for increasing dye adsorption to enhance power conversion efficiency of DSSC. Moreover, the fabricated cell based on two-step etched films exhibits maximum power conversion efficiency and better fill factor due to the formation of fine porous structure. Therefore, these results implied that the roles of etching processes are improving specific surface area and fine porous formation which can provide better dye adsorption and redox process for DSSC application.

\section{Additional Points}

The paper highlights the following points. (i) Power conversion efficiency of $\mathrm{ZnO}$ dye-sensitized solar cell is enhanced by surface modification of porous photoelectrode. (ii) Porous $\mathrm{ZnO}$ films are successfully modified by etching process, providing increased dye adsorption and better redox process. (iii) Short-circuit current density is directly changed with the amount of dye adsorption, resulting in enhanced power conversion efficiency.

\section{Competing Interests}

The authors declare that they have no competing interests.

\section{Acknowledgments}

This work was supported by CMU Mid-Career Research Fellowship program, Chiang Mai University. Sutthipoj Sutthana would like to acknowledge Energy Policy and Planning Office, Ministry of Energy, and Graduate School, Chiang Mai University, for financial support.

\section{References}

[1] J. Lin, A. Nattestad, H. Yu et al., "Highly connected hierarchical textured $\mathrm{TiO}_{2}$ spheres as photoanodes for dye-sensitized solar cells," Journal of Materials Chemistry A, vol. 2, no. 23, pp. 89028909, 2014.

[2] F. Li, G. Wang, Y. Jiao, J. Li, and S. Xie, "Efficiency enhancement of $\mathrm{ZnO}$-based dye-sensitized solar cell by hollow $\mathrm{TiO}_{2}$ nanofibers," Journal of Alloys and Compounds, vol. 611, pp. 1923, 2014.

[3] A. Hagfeldt, G. Boschloo, L. Sun, L. Kloo, and H. Pettersson, "Dye-sensitized solar cells," Chemical Reviews, vol. 110, no. 11, pp. 6595-6663, 2010.
[4] Q. Wali, A. Fakharuddin, and R. Jose, "Tin oxide as a photoanode for dye-sensitised solar cells: current progress and future challenges," Journal of Power Sources, vol. 293, pp. 1039-1052, 2015.

[5] W. L. Hoffeditz, M. J. Katz, P. Deria et al., "High-surface-area architectures for improved charge transfer kinetics at the dark electrode in dye-sensitized solar cells," ACS Applied Materials and Interfaces, vol. 6, no. 11, pp. 8646-8650, 2014.

[6] C. Fei, J. Tian, Y. Wang et al., "Improved charge generation and collection in dye-sensitized solar cells with modified photoanode surface," Nano Energy, vol. 10, pp. 353-362, 2014.

[7] K. Hongsith, N. Hongsith, D. Wongratanaphisan et al., "Sparking deposited $\mathrm{ZnO}$ nanoparticles as double-layered photoelectrode in $\mathrm{ZnO}$ dye-sensitized solar cell," Thin Solid Films, vol. 539, pp. 260-266, 2013.

[8] X. Xu, F. Qiao, L. Dang, Q. Lu, and F. Gao, "Porous tin oxide nanosheets with enhanced conversion efficiency as dyesensitized solar cell electrode," The Journal of Physical Chemistry C, vol. 118, no. 30, pp. 16856-16862, 2014.

[9] A. Al-Kahlout, "Thermal treatment optimization of $\mathrm{ZnO}$ nanoparticles-photoelectrodes for high photovoltaic performance of dye-sensitized solar cells," Journal of the Association of Arab Universities for Basic and Applied Sciences, vol. 17, pp. 66-72, 2015.

[10] C. Xu, L. Deng, A. Holder et al., "Nanoparticle and nanosphere mask for etching of ITO nanostructures and their reflection properties," Physica Status Solidi (A) Applications and Materials Science, vol. 212, no. 1, pp. 171-176, 2015.

[11] S. Sutthana, D. Wongratanaphisan, A. Gardchareon, S. Phadungdhitidhada, P. Ruankham, and S. Choopun, "Enhancement of $\mathrm{ZnO}$ dye-sensitized solar cell performance by modifying photoelectrodes using an acid vapor texturing process," Surface \& Coatings Technology, In press.

[12] S. Pearton, W. Lim, F. Ren, and D. Norton, "Wet chemical etching of wide bandgap semiconductors- $\mathrm{GaN}, \mathrm{ZnO}$ and $\mathrm{SiC}$," ECS Transactions, vol. 6, no. 2, pp. 501-512, 2007.

[13] J. Zhao, Z. G. Jin, T. Li, and X. X. Liu, "Preparation and characterization of $\mathrm{ZnO}$ nanorods from $\mathrm{NaOH}$ solutions with assisted electrical field," Applied Surface Science, vol. 252, no. 23, pp. 8287-8294, 2006.

[14] S. Fernández, O. de Abril, F. B. Naranjo, and J. J. Gandía, "Etching process optimization using $\mathrm{NH}_{4} \mathrm{Cl}$ aqueous solution to texture $\mathrm{ZnO}: \mathrm{Al}$ films for efficient light trapping in flexible thin film solar cells," Thin Solid Films, vol. 520, no. 12, pp. 4144-4149, 2012.

[15] X. Fang, Y. Li, S. Zhang, L. Bai, N. Yuan, and J. Ding, “The dye adsorption optimization of $\mathrm{ZnO}$ nanorod-based dye-sensitized solar cells," Solar Energy, vol. 105, pp. 14-19, 2014.

[16] S. S. Ng, P. K. Ooi, S. Yaakob, M. J. Abdullah, H. A. Hassan, and Z. Hassan, "Fabrication of porous $\mathrm{ZnO}$ thin films via ammonium hydroxide: effects of etching time and oxidizer on surface morphology and surface roughness," Sains Malaysiana, vol. 43, no. 7, pp. 1077-1082, 2014.

[17] N. V. Tellabati, Y. B. Waghadkar, A. Roy et al., "Optical and photovoltaic properties of temperature-dependent synthesis of $\mathrm{ZnO}$ nanobelts, nanoplates, and nanorods," Journal of Solid State Electrochemistry, vol. 19, no. 8, pp. 2413-2420, 2015.

[18] P. G. Seybold, M. Gouterman, and J. Callis, "Calorimetric, photometric and lifetime determinations of fluorescence yields of fluorescein dyes," Photochemistry and Photobiology, vol. 9, no. 3, pp. 229-242, 1969. 
[19] F. Zhang, F. Shi, W. Ma et al., "Controlling adsorption structure of eosin y dye on nanocrystalline $\mathrm{TiO}_{2}$ films for improved photovoltaic performances," Journal of Physical Chemistry C, vol. 117, no. 28, pp. 14659-14666, 2013.

[20] H. Du, R. C. A. Fuh, J. Li, L. A. Corkan, and J. S. Lindsey, "PhotochemCAD: a computer-aided design and research tool in photochemistry," Photochemistry and Photobiology, vol. 68, no. 2, pp. 141-142, 1998.

[21] K. Fan, W. Zhang, T. Peng, J. Chen, and F. Yang, "Application of $\mathrm{TiO}_{2}$ fusiform nanorods for dye-sensitized solar cells with significantly improved efficiency," Journal of Physical Chemistry C, vol. 115, no. 34, pp. 17213-17219, 2011.

[22] H. Wang, B. Wang, J. Yu et al., "Significant enhancement of power conversion efficiency for dye sensitized solar cell using 1D/3D network nanostructures as photoanodes," Scientific Reports, vol. 5, article 9305, 2015.

[23] R. Katoh and A. Furube, "Electron injection efficiency in dyesensitized solar cells," Journal of Photochemistry and Photobiology C: Photochemistry Reviews, vol. 20, pp. 1-16, 2014.

[24] W. Li, J. Yang, Q. Jiang et al., "Bi-layer of nanorods and threedimensional hierarchical structure of $\mathrm{TiO}_{2}$ for high efficiency dye-sensitized solar cells," Journal of Power Sources, vol. 284, pp. 428-434, 2015.

[25] S. Yang, H. Kim, S.-H. Ahn, and C. S. Lee, "The effect of the agglomerated microstructure of dry-deposited $\mathrm{TiO}_{2}$ electrodes on the performance of dye-sensitized solar cells," Electrochimica Acta, vol. 166, pp. 117-123, 2015.

[26] M. Marandi, M. Pirhadi, and R. Davarnejad, "Facile modified cyclic electrophoretic deposition of hydrothermally prepared $\mathrm{TiO}_{2}$ nanocrystals and their application in dye sensitized solar cells," Journal of Alloys and Compounds, vol. 646, pp. 264-270, 2015.

[27] J. Bisquert, F. Fabregat-Santiago, I. Mora-Seró, G. GarciaBelmonte, and S. Giménez, "Electron lifetime in dye-sensitized solar cells: theory and interpretation of measurements," The Journal of Physical Chemistry C, vol. 113, no. 40, pp. 17278-17290, 2009.

[28] Y. Dou, F. Wu, C. Mao, L. Fang, S. Guo, and M. Zhou, "Enhanced photovoltaic performance of $\mathrm{ZnO}$ nanorod-based dye-sensitized solar cells by using Ga doped $\mathrm{ZnO}$ seed layer," Journal of Alloys and Compounds, vol. 633, pp. 408-414, 2015.

[29] Z. Lan, L. Que, W. Wu, and J. Wu, "Preparation of Pt-NiO/ $\mathrm{Co}_{3} \mathrm{O}_{4}$ nanocompounds based counter electrodes from Pt$\mathrm{Ni} / \mathrm{Co}$ alloys for high efficient dye-sensitized solar cells," Journal of Alloys and Compounds, vol. 646, pp. 80-85, 2015.

[30] J. A. Anta, E. Guillén, and R. Tena-Zaera, "ZnO-based dyesensitized solar cells," Journal of Physical Chemistry C, vol. 116, no. 21, pp. 11413-11425, 2012.

[31] Q. Zhang, C. S. Dandeneau, X. Zhou, and C. Cao, "ZnO nanostructures for dye-sensitized solar cells," Advanced Materials, vol. 21, no. 41, pp. 4087-4108, 2009.

[32] A. Fakharuddin, R. Jose, T. M. Brown, F. Fabregat-Santiago, and J. Bisquert, "A perspective on the production of dye-sensitized solar modules," Energy \& Environmental Science, vol. 7, no. 12, pp. 3952-3981, 2014. 

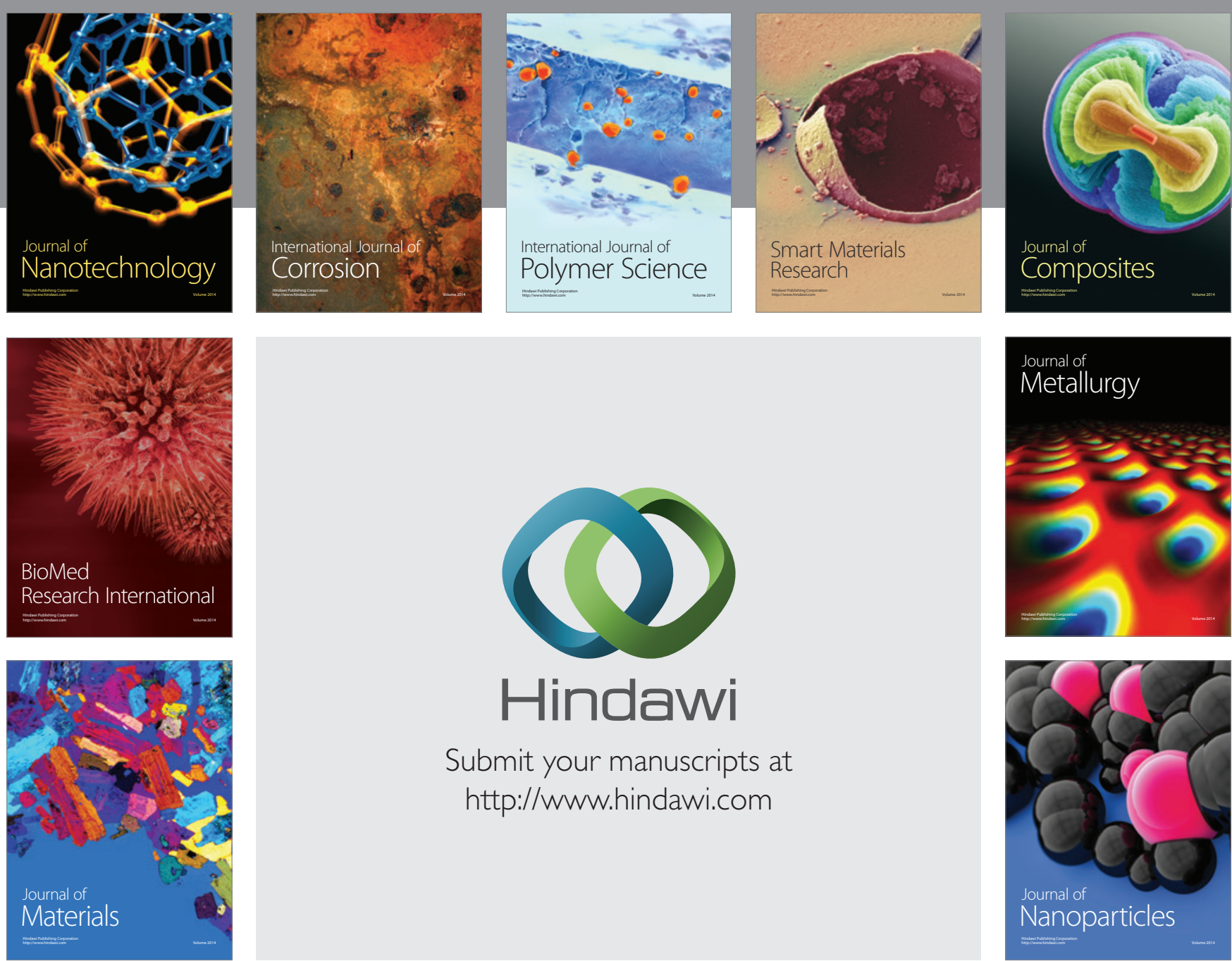

\section{Hindawi}

Submit your manuscripts at

http://www.hindawi.com

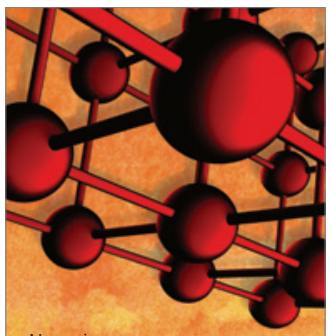

Materials Science and Engineering
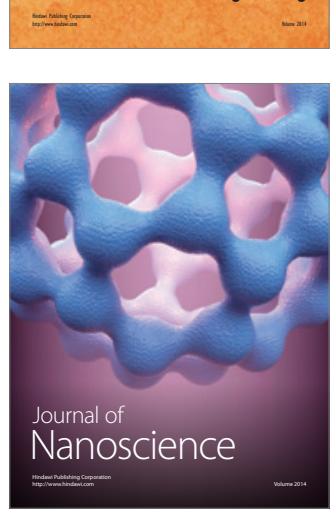
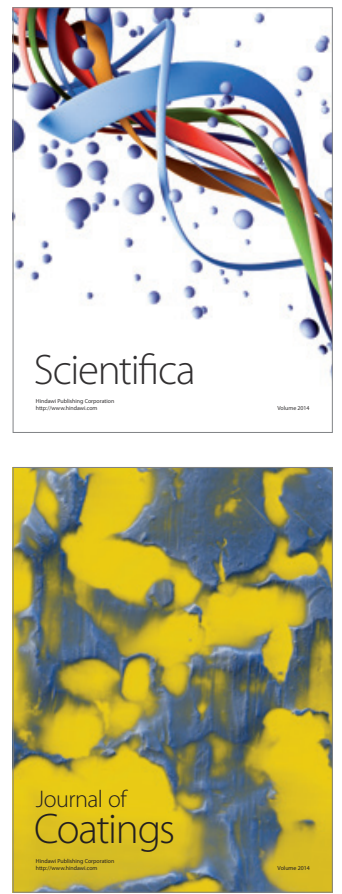
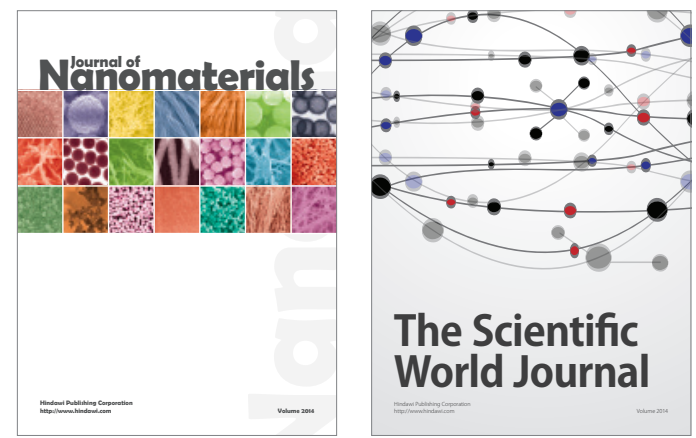

The Scientific World Journal
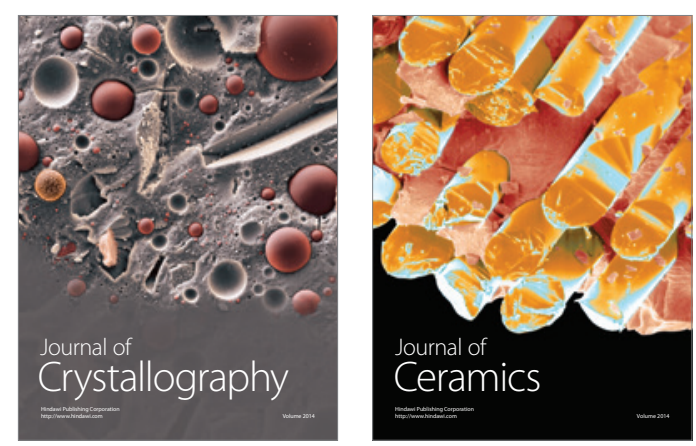
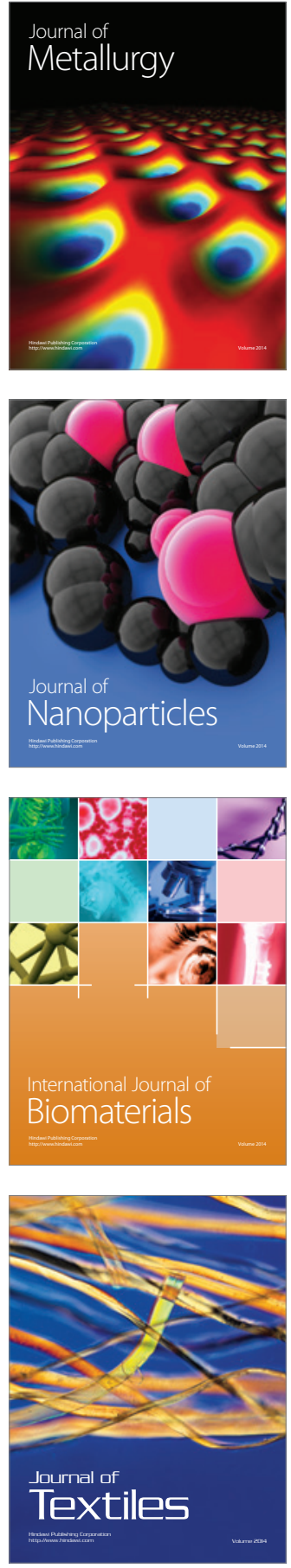